\title{
Review:
}

\section{Utility of the browser's behavioural and physiological strategies in coping with dietary tannins: Are exogenous tannin-inactivating treatments necessary?}

\author{
V. Mlambo $\#$, U. Marume \& C.S. Gajana \\ Department of Animal Science, Faculty of Agriculture, Science and Technology, North-West University, \\ P Bag X2046, Mmabatho 2735, Mafikeng, South Africa
}

(Received 10 October 2014; Accepted 19 October 2015; First published online 9 November 2015)

\begin{abstract}
Copyright resides with the authors in terms of the Creative Commons Attribution 2.5 South African Licence.
See: http://creativecommons.org/licenses/by/2.5/za

Condition of use: The user may copy, distribute, transmit and adapt the work, but must recognise the authors and the South African Journal of Animal Science.
\end{abstract}

\begin{abstract}
The desire to reduce feeding costs in small-ruminant production systems has led to increased reliance on non-conventional locally available browse products as protein supplements. Browse products contain variable quantities of tannins, whose nutritional effects on the animal can be positive or negative. Because of the lack of rapid evaluation techniques and methods that can differentiate, accurately, between potentially beneficial and harmful tannins, most researchers employ a 'safety first' approach in which tannin-inactivating treatments are applied to browse products to protect the animal and enhance feed utilization. This is despite the fact that browsing herbivores are known to have various behavioural and physiological strategies to cope with a number of anti-nutritional plant compounds, which include tannins. In this paper, the authors explore the rationale behind recommending the use of tannin-neutralization strategies when feeding animals with browse leaves and fruits. Are browsing herbivores' own coping strategies sufficient to protect them from suboptimal nutrition and possible toxicity caused by tannins or is intervention always required? In an attempt to answer this question, this review presents the current state of knowledge of tannins in ruminant nutrition before summarizing the strategies that browsing herbivores use to cope with tannins and their potential utility in various rearing systems. Finally, the utility of exogenous tannin inactivation strategies and the animals' own coping strategies are compared. Feeding scenarios are identified in which exogenous inactivation strategies may be worthwhile.
\end{abstract}

Keywords: Condensed tannins, proline-rich salivary protein, post-ingestive feedback, tannin inactivation, microbial adaptations, polyethylene glycol

\#Correspondence: Victor.Mlambo@nwu.ac.za; victormlambo@yahoo.co.uk; victormlambo@icloud.com

\section{Introduction}

Herbivores, whose normal diet contains tannins, have been shown to possess a variety of coping strategies that protect them from negative nutritional and health effects (Estell, 2010; Ammar et al., 2011). The effectiveness of these coping strategies under various feeding systems is mostly unknown, and is confounded by the complex structure-activity relationships in tannins (Barry \& McNabb, 1999; Santos-Buelga \& Scalbert, 2000; Mueller-Harvey, 2006). As a result, attempts have been made to design, investigate and implement exogenous strategies that modify tannin levels and their in vivo reactivity to aid the herbivore in utilizing tannin-containing feedstuffs.

Tannins are a highly heterogeneous group of phenolic compounds that are produced by plants as part of their secondary metabolism. Over the years, several researchers (Makkar, 2003; Mlambo et al., 2004; Mueller-Harvey et al., 2007) have attempted to define the nutritional effects of tannins in browsing herbivores that encounter these compounds in their diets. The nutritional consequences of these compounds are ambiguous, with positive and negative effects being reported (Mueller-Harvey, 2006). This is attributed mostly to the high structural diversity of tannins, which determines their nutritional consequences. Greater attention has been paid to the role of tannins in ruminant nutrition, because of increased use of nonconventional locally available browse products as protein supplements in semi-intensive and extensive small-ruminant production systems (Aganga \& Tshwenyane, 2003; Mlambo et al., 2004; Rogosic et al., 
2008). Indeed, the roles of trees and shrubs as feed resources in semi-arid regions of the world need no further emphasis.

Most researchers recommend the collection and storage of browse products such as fruits for later use in drier seasons. Under these feeding conditions, there is concern that the animals' coping strategies could be insufficient and negative effects of tannins might reduce or negate the benefit of supplementing animals with tannin-containing browse products. As a result, a number of interventions that were designed to neutralize tannins and related compounds have been investigated and recommended, particularly the use of polyethylene glycol (PEG) (Gilboa et al., 2000; Silanikove et al., 2001; Villalba \& Provenza, 2002; Smith et al., 2003; Mlambo et al., 2004; 2007; 2011; Mlambo \& Mapiye, 2015), despite the fact that herbivores that routinely consume tannin-containing feedstuffs have been shown to possess strategies to circumvent negative dietary effects of tannins. These strategies include avoidance mechanisms (the bitter rejection response as postulated by Glendinning (1994)), secretion of proline-rich salivary proteins (PRPs), ruminal microbial physiological responses and hepatic detoxification activity. Therefore, the question is whether animals' own coping strategies are sufficient to mitigate suboptimal nutrition and avoid possible toxicity caused by tannins. A follow-up question is whether it is prudent to invest time and money on strategies to neutralize possible anti-nutritional effects of tannins in free-ranging and confined browsers? In an attempt to shed some light on these questions, this review paper explores the efficacy of herbivores' natural coping strategies, and juxtaposes the findings with the reported effectiveness of exogenous tannin-neutralizing approaches in mitigating the negative effects of condensed tannins.

\section{Tannins and the nutrition of herbivores}

Tannins are a complex group of polyphenolic compounds that occur in many feeds such as fodder legumes, browse leaves and fruits (Hedqvist et al., 2000). There are two major groups of tannins: hydrolysable tannins (HTs) and condensed tannins (CTs) (Figure 1). HTs are made up of a carbohydrate core whose hydroxyl groups are esterified with phenolic acids (mainly gallic and hexahydroxydiphenic acid) (Mueller-Harvey \& McAllan, 1992). CTs or proanthocyanidins are non-branched polymers of flavonoids units (flavan-3-ol, flavan-3,4-diol), and usually have a higher molecular weight than HTs (1000-20000 Da compared with 500-3000 Da) (Mueller-Harvey, 1999). HTs tend to attract less attention from animal nutritionists than CTs, presumably because they are easily broken down in the digestive system of animals. However, HTs of low molecular weight and products of HT hydrolysis may be the cause of toxicity in animals. Terblance (1967) reported fatalities in goats that had consumed Acacia nilotica fruits, which are known to contain high levels of epigallocatechin gallates (Mlambo et al., 2007).<smiles>O=C(OCC1OC(=O)[C@H](OC(=O)c2cc(O)c(O)c(O)c2)[C@@H](OC(=O)c2cc(O)c(O)c(O)c2)[C@@H]1COC(=O)c1cc(O)c(O)c(O)c1)c1cc(O)c(O)c(O)c1</smiles>

Hydrolysable tannin

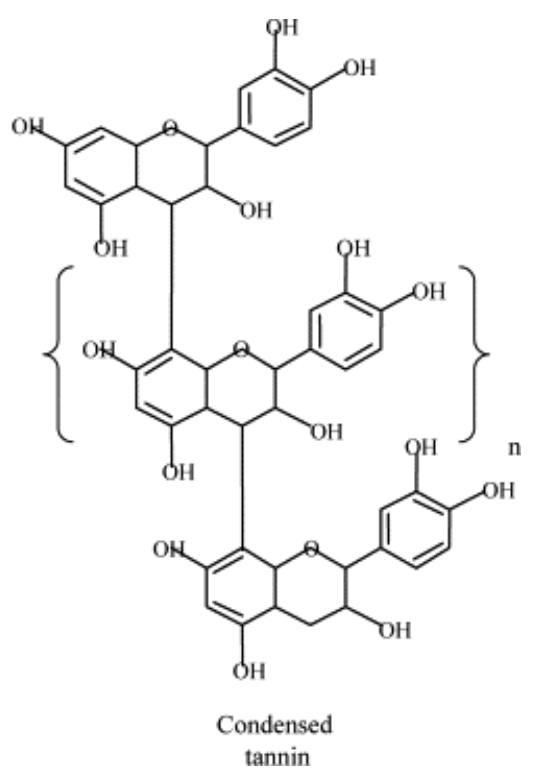

Figure 1 Diagrammatic representation of hydrolysable and condensed tannins (Krause et al., 2005).

Numerous attempts have been made to predict the effect of tannins on animal nutrition and health, with variable success. This is hardly surprising, given that the nutritional effects of tannins depend on factors 
such as concentration, molecular weight and structure, as well as animal factors. Beneficial tannin effects include reduction in internal parasite load (Athanasiadou et al., 2000; 2001; Hoskin et al., 2000), prevention of frothy bloat when animals consume pastures that are rich in soluble proteins (Griffiths, 1991), improved nitrogen utilization efficiency (Mlambo et al., 2004; Waghorn, 2008), reduced enteric methanogenesis, and reduced nitrogen pollution through animal waste. On the other hand, astringency and negative post-ingestive effects of tannins cause reduced voluntary feed intake in the short term (Aganga \& Tshewenyane, 2003). Silanikove et al. (1997) reported an inverse relationship between tannins and the degradation rate and digestibility of substrates in the digestive tract of ruminants. This ultimately reduces the amount of nutrients absorbed from the digestive tract. Other negative effects of tannins include toxicity, erosion of gastrointestinal tract and even animal deaths (Terblance et al., 1967). It is primarily the negative effects of tannins on voluntary feed intake and nutrient digestion that have resulted in indiscriminate use of exogenous tannin-inactivating treatments of tannin-containing feeds.

The desire to improve feed intake and enhance nutrient bioavailability has resulted in the use of exogenous tannin-neutralizing treatments, particularly in feeding systems in which tannin-rich feedstuffs are used as protein supplements. Under feeding conditions in which the basal diet is protein deficient, the primary objective should be to meet the nitrogen requirements of rumen microbes. The presence of tannins in protein forages is a constraint to attaining optimal ruminal nitrogen concentration for maximum microbial activity. The use of tannin-inactivating compounds seems to be the easiest and fastest way to resolve this problem. However, contradictory results were obtained when these inactivating compounds were used. The challenge for scientists is that currently there are few, if any, rapid methods to differentiate reliably between potentially beneficial and harmful tannins (Muller-Harvey et al., 2007). Table 1 presents a summary of the nutritional benefits obtained through neutralizing tannins with PEG. These findings have encouraged the widespread use of detannifying strategies in which non-conventional tannin-rich forage is used. This may be a waste of scarce resources, given that animals' adaptive mechanisms may adequately neutralize the nutritional threat posed by tannins. In addition, some of the tannins that are 'removed' from the diet could be beneficial to the animal (Mlambo et al., 2004).

Table 1 Polyethylene glycol (PEG) as a diagnostic tool for in vivo effects of tannins in goats

\begin{tabular}{|c|c|c|c|}
\hline Reference & Rate of PEG & Diet offered & Findings \\
\hline Mkhize et al., 2015 & 20 g/animal/day & $\begin{array}{l}\text { Free-ranging goats. The } \\
\text { rangeland is dominated by } \\
\text { Acacia karroo, Acacia tortilis, } \\
\text { Ziziphus mucronata, and some } \\
\text { Euclea species. Lippia rehmannii } \\
\text { and Tarconanthus camphoratus } \\
\text { herbs }\end{array}$ & $\begin{array}{l}\text { Dosing animals with PEG } \\
\text { increased use of tannin-containing } \\
\text { woody plants. Unsupplemented } \\
\text { goats spent more time grazing } \\
\text { than browsing }\end{array}$ \\
\hline $\begin{array}{l}\text { Fagundes et al., } \\
2014\end{array}$ & 60 g/animal/day & $\begin{array}{l}\text { Tifton } 85 \text { hay, which was } \\
\text { replaced by flemingia leaf hay at } \\
0 \%, 12.5 \% \text { and } 25 \% \text { rates }\end{array}$ & $\begin{array}{l}\text { PEG increased intake and } \\
\text { digestion of tannin-rich flemingia } \\
\text { leaf hay. No effect was observed } \\
\text { on milk yield }\end{array}$ \\
\hline $\begin{array}{l}\text { Narvaez et al., } \\
2011\end{array}$ & $\begin{array}{c}0.05 \%-0.3 \% \text { body } \\
\text { weight/day }\end{array}$ & $\begin{array}{l}\text { Fresh evergreen branches } \\
\text { (leaves and stems) of condensed } \\
\text { tannin-rich Arctostaphylos } \\
\text { canescens Eastw }\end{array}$ & $\begin{array}{l}\text { Dosing with PEG increased feed } \\
\text { intake, nutrient digestibility and } \\
\text { weight gain }\end{array}$ \\
\hline $\begin{array}{l}\text { Mlambo et al., } \\
2004\end{array}$ & $\begin{array}{l}20 \mathrm{~g} \text { PEG/100 g } \\
\text { Dichrostachys } \\
\text { cinerea fruit }\end{array}$ & $\begin{array}{l}\text { Mature and ripe Dichrostachys } \\
\text { cinerea fruits ( } 200 \text { g/animal/day) } \\
\text { milled through a } 4-\mathrm{mm} \text { screen. } \\
600 \text { g/day grass hay }\end{array}$ & $\begin{array}{l}\text { PEG treatment resulted in } \\
\text { excessive protein degradation in } \\
\text { the rumen leading to high urine } \mathrm{N} \\
\text { loss and low } \mathrm{N} \text { retention values. } \\
\text { Untreated fruits promoted higher } \mathrm{N} \\
\text { retention values }\end{array}$ \\
\hline
\end{tabular}

Until the early 2000s, it was understood that high concentrations of tannins tended to have negative nutritional effects, whereas low to moderate concentrations had beneficial effects. Barry (1989) suggested that a condensed tannin level at $2 \%-4 \%$ of DM in the diet would increase protein flow into the duodenum, 
resulting in improved growth. Later, Barry \& McNabb (1999) reported that CTs at concentrations lower than $50 \mathrm{~g} / \mathrm{kg}$ DM did not affect most ruminal fermentation parameters. An upper limit of $5 \mathrm{~g} \mathrm{CT} / 100 \mathrm{~g}$ DM was proposed by Min et al. (2003) as a safe level. However, more recent findings on in vivo tannin activity indicate that dependence on the quantity of tannins as a predictor of in vivo effects is unreliable. Using Dichrostachys cinerea fruits containing nearly 50\% DM of tannins, Mlambo et al. (2004) demonstrated that neutralizing the tannins with PEG negatively affected the nutrient retention capacity of indigenous Matabele goats. Untreated fruits promoted higher nitrogen retention values, suggesting that even at high levels, some tannins still have beneficial effects on animal nutrition. In later studies with tannins from $D$. cinerea and other browse plants that are common in semi-arid regions, Mueller-Harvey et al. (2007) revealed that while the quantity of tannin is an important factor, the structure of the tannin matters more. Thus, several factors influence whether tannins exert positive or negative effects on browsers. Frutos et al. (2004) identified some of these factors as types of tannin, chemical structure and molecular weight of tannin, amount ingested, and animal species.

\section{Browser coping strategies}

Plants produce diverse mixtures of biochemicals, particularly secondary compounds that provide herbivores with challenges in accessing nutrients for survival and reproduction. While some compounds may be beneficial, most can be detrimental to rumen microbial populations, interfere with digestion processes, cause intestinal damage and result in metabolic toxicity post absorption (Rogosic et al., 2008). Browsers therefore cope with these toxic plant compounds through behavioural responses, physiological mechanisms and microbial adaptations.

\section{Behavioural responses}

Behavioural responses refer to animal strategies to reduce or eliminate consumption of anti-nutritional plant compounds through behavioural changes. These behavioural changes, which vary according to production system (free-ranging or intensive), include avoidance and aversion (pre-ingestive cues, and regulating intake below a threshold via conditioned antipathies) (Burritt \& Provenza, 2000), neophobia (Owen, 1992), differential and cautious sampling (selecting plants or plant parts with lower concentrations) (Dziba \& Provenza, 2008), increasing diet breadth, food imprinting (learning from parents), associative learning (social interactions and feedback) (Duncan \& Young, 2002; Estell, 2010), altering the frequency and length of feeding bouts (cyclic consumption) and plant secondary metabolite complementarity (Rogosic et al., 2008).

Avoidance and aversion occur when animals perceive and respond to flavours and flavour intensities created by the integration of odour, taste and texture of the feed. This allows them to detect and avoid certain plants or plant parts, thus modifying feeding behaviour accordingly (Burritt \& Provenza, 2000; Estell, 2010). Avoidance can be innate, where animals are apparently genetically programmed with knowledge of plant palatability, and thus are attracted to sweet flavours and repelled by bitter flavours (Owen, 1992). In this case, animals avoid or are reluctant to eat feeds that are high in antifeedants without prior experience, a condition normally referred to as neophobia. However, there is a dearth of information to confirm this. Nevertheless, goats may demonstrate an aversion to certain plant biochemicals through learning from postingestion consequences or feedback. In goats, the consumption of some toxic plants may elicit postingestive stimuli to the brain about the effect(s) the feed is having on the animal (Provenza, 1995). This causes a negative feedback effect, culminating in the animal making an unconscious association between plant flavour (taste and odour) and the resultant negative digestive feedback (Duncan \& Young, 2002; Estell, 2010). This ultimately results in avoidance or aversion (hedonic shift) from that feed because of past negative associations. With some toxins that supposedly taste bitter (e.g. alkaloids, saponins and cyanogenic glycosides) or provoke an astringent sensation when eaten (e.g. tannins), a bitter rejection response could be elicited, consisting of a suite of withdrawal reflexes and negative affective responses (Glendinning, 1994). Nonetheless, bitter response thresholds vary independently of toxicity thresholds, indicating that the bitter rejection response can be elicited by a harmless bitter food.

Feed imprinting and associative learning are behavioural ways in which goats cope with plant secondary metabolites. Feed imprinting provides offspring with an efficient means of optimizing their subsequent behaviours towards certain feeds. Provenza et al. (1993) observed that young animals learn from their mother's example to eat preferred feeds and avoid feeds with toxins. However, while the mother is an important source of information for young animals, post-ingestive consequences are probably more critical (Provenza et al., 1993). Learning can occur through associational cues that alert an animal to an aversive compound that is imperceptible prior to consumption and post-ingestive effects (Moore et al., 2004; Estell, 2010). Goats, like other domestic livestock, are social animals. They frequently observe one another and modify their diet selection according to what their grazing companions are eating (Thorhallsdottir et al., 
1990). Learning can also take place through trial and error. However, trial and error learning can be risky as sampling toxic plants is imprecise, and errors while sampling could be debilitating or lethal (Provenza et al., 1992).

Differential and cautious sampling (selecting plants or plant parts with lower concentrations), increasing diet breadth, altering the frequency and length of feeding bouts (cyclic consumption) (Perevolotsky et al., 2006; Dziba \& Provenza, 2008) and consuming plants with complementary secondary metabolites are other ways in which goats can cope with the effects of secondary plant metabolites (Provenza et al., 1992; Estell, 2010). Cautious sampling enhances the consumption of secondary plant metabolites with toxic threshold limits and allows detoxification enzymes to be maintained at an induced state as a protective mechanism in the event of plant secondary metabolites consumption (McLean \& Duncan, 2006). Cyclic consumptions and increasing dietary breadths may reduce the cumulative effects of secondary plant metabolites (Provenza et al., 1992). Additionally, ample time is allowed for the detoxification process to be completed before more toxic metabolites are consumed. It has been observed that goats can limit the effects of toxins in a single plant by mixing diets (Provenza, 1996). Variable chemical composition of toxins in different plant species suggests variable and different detoxifications pathways in animals. Marsh et al. (2006) therefore proposed the detoxification limitation theory, which assumed that animals could consume more toxin-containing forages of greater chemical diversity because detoxification is spread over more metabolic pathways, thereby reducing the constraints on enzymes and substrates. Rogosic et al. (2007) observed that complementary relationships among classes of secondary plant metabolites influence the toxicity of chemicals and amount of feed ingested. For example, in goats and sheep, the consumption of tannins and saponins simultaneously was observed to reduce the toxic effects of these chemicals and increase feed intake compared with the consumption of the two classes of chemicals in isolation (Rogosic, 2007; 2008; Estell, 2010).

From a synthesis of the literature, there is evidence that browsing herbivores are well equipped with behavioural responses that should allow them to overcome the challenges posed by secondary plant compounds in their diet. It is therefore tempting to conclude that scientists should not be concerned with the negative effects of dietary tannins when fed to browsers. However, most of these behavioural responses may be curtailed under restrictive rearing and feeding systems, hence their importance should be viewed in this light. Clearly, browsers benefit most from these behavioural strategies if they are allowed to express their natural feeding habits. Browsers reared under intensive production systems may not exhibit the whole range of behavioural strategies, as these would depend on what the animal was offered. Even for free-ranging browsers, behavioural strategies could be constrained by fluctuations in feed quantity and quality.

\section{Physiological mechanisms}

Complementary to changes in feeding behaviour, browsers possess physiological mechanisms that influence how they cope with secondary plant metabolite consumption (Estell, 2010). These mechanisms include the production of salivary proline-rich proteins (PRPs), microbial ruminal fermentation, and liver and stomach wall detoxification (Jason \& Murray, 1996; Estell, 2010).

Proline-rich proteins are salivary proteins with high affinity for polyphenolic compounds such as tannins. In saliva, they constitute up to $70 \%$ of total parotid protein. PRPs can form stable complexes with tannins in consumed forages, consequently protecting animals from anti-nutritional effects (Mehansho et al., 1987). Part of this protection may be through diminished intestinal uptake of tannin caused by the insoluble tannin-PRP complexes. In vitro studies have shown that most insoluble tannin-PRP complexes formed under conditions in the mouth remain insoluble when exposed to environments similar to those of the stomach and the intestines, and hence intestinal absorption will not occur (Mehansho et al., 1987). This has implications for the protein economy of animals since PRP are lost in faeces and therefore this physiological response is taxing on animals' protein pools. Secretion of PRPs constitutes the first line of defence against ingested tannins in some rodents (Mehansho et al., 1987). This is supported by findings that feeding tannins to rats resulted in a decreased growth rate, but after a few days, the growth returned to normal concomitantly with a marked stimulation of PRP synthesis (Mehansho et al., 1983, 1985).

Goats are normally referred to as mixed feeders and have been hypothesized to produce PRPs as a means of coping with the consumption of tannins. However, Distel \& Provenza (1991) detected no significant amounts of PRPs in goat saliva, regardless of whether they had been adapted to a high-tannin diet or not. Additionally, in grazing and strictly browsing ruminants, secretion of PRPs did not appear to be affected by dietary tannin levels (Makkar \& Becker, 1998; Clauss et al., 2003). Nevertheless, recent observations indicate that when exposed to tannin-rich diets, goats have the ability to secrete PRPs that complex with tannins and reduce their detrimental effects (Mueller-Harvey, 2006; Alonso-Díaz et al., 2010). Gilboa et al. (1995) detected high amounts of proline (6.5\%), glutamine (16.5\%) and glycine (6.1\%) in goat saliva when goats were exposed to tannin-rich feeds. These amino acids are known to enhance the affinity of proteins 
with tannins (Mehansho et al., 1987). These tannin-PRP complexes are generally stable and essentially inactivate tannins and reduce their absorption and toxicity (Shimada, 2006). All these observations explain why goats are able to consume higher amounts of browse than sheep and cattle, and are better able to cope with tannins than other domestic animals (Salem et al., 2006; Rogosic et al., 2008; Utsumi et al., 2009).

After the tannin and other secondary metabolites enter the gut, they may be modified by rumen microbes (discussed below) or absorbed into the bloodstream, at which point liver detoxification becomes critical. The liver contains enzyme systems that metabolize nonpolar compounds, which are normally toxic, into water-soluble compounds that can be excreted through the urine (Pfister, 1999). Hervas et al. (2003) demonstrated hepatic detoxification function in response to incremental levels of dietary quebracho tannin extract in sheep. Although most detoxification takes place in the liver cells and the kidney, the stomach and intestinal mucosa, lungs and skin play critical roles (Zimmerman, 1978; Pfister, 1999). Liver detoxification has advantages over microbial detoxification in that, first, liver enzymes are under genetic control, and hence protection can be passed on from generation to generation. Second, liver enzyme systems are variable and can handle a diversity of toxins, and, third, toxin stimulation of liver enzymes is rapid, hence the enzymes become active at a slight elevation of toxin levels (Foley et al., 1999; Pfister, 1999). Liver detoxification, however, is dependent on the nutritional status of the animal and the provision of adequate dietary nutrients (protein, energy, including water) (Villalba et al., 2002; Utsumi et al., 2009). Protein and energy status are both critical for detoxification because processes such as synthesis of detoxification enzymes, modifications of the toxins for excretion, and maintenance of acid/base balance required protein and energy (Illius \& Jessop, 1995; Foley et al., 1999).

\section{Microbial adaptations}

In addition to the production of PRPs, tannins can be degraded in the rumen via microbial pre-gastric fermentation (Freeland \& Janzen, 1974). The utilization of toxic plants in browsers is made possible by the massive numbers of microbes in the rumen, where millions of microbes may be found per millilitre of rumen contents (Pfister, 1999; Duncan et al., 2000). Some of these microbes are capable of degrading or detoxifying some plant toxins (Estell, 2010). For hydrolysable tannins and saponins, there seems to be a dependence on the detoxification process of these compounds in the rumen, probably because of degradation of these compounds by bacteria (Newbold et al., 1997; Teferedegne, 2000). Weimer (1998), however, reported that rumen microbial degradation occurs only where these toxic compounds are an energy source for microbes. Microbes must also inhabit a particular rumen niche that allows them to survive when the toxin is not present, and increase their population rapidly when the toxin enters the rumen (Pfister, 1999; Cardozo et al., 2004; Busquet et al., 2005). Conversely, microbial metabolism of some secondary plant metabolites can result in the conversion of innocuous substances into toxic compounds (Estell, 2010). For example, Kakes (1991) and Majak (2001) observed that microbial hydrolysis of cyanoglucosides and glucosinolates to sugars and aglycones releases toxic cyanide and thiocyanates, respectively.

Cardozo et al. (2004) and Busquet et al. (2005) observed that the induction of microbial adaptations lasts only a few days for some plant extracts, suggesting that ruminal microorganisms adapt to the compounds with time. Duncan et al. (1997) also noted that rumen microbial population could respond rapidly to dietary changes, and adaptation to secondary plant metabolites could occur in a few days. These adaptive mechanisms include the secretion of exo-polysaccharide (EPS) to form a protective layer around cells, dissociation of tannin-substrate complexes and formation of a thick glycocalyx or glycoprotein, which has high binding affinity for tannin (Nicholson et al., 1986; Chiquette et al., 1988; Smith et al., 2005). Mlambo et al. (2007) also provide evidence that rumen fluid from animals that consume tannin-rich feeds (adapted) is better able to ferment tannin-containing substrates in vitro than rumen fluid from unadapted animals. This points to the existence of adapted rumen microbes capable of modifying the anti-nutritional effects of tannins. Exo-polysaccharides have been shown to improve the survival of some species of Lactobacillus or to act as a protective barrier for some tannin-resistant ruminal Streptococci such as Streptococcus gallolyticus against the antimicrobial action of tannic acid (O 'Donovan \& Brooker, 2001). The EPS is not only a molecular sieve, but harbours enzymes (tannic acid hydrolase, gallate decarboxylase) in the matrix, which probably catalyses reactions that reduce access of potentially toxic substance to the microorganisms (Krause et al., 2005). Nevertheless, these protective functions have not been demonstrated for many Lactobacillus spp. Nicholson et al. (1986) demonstrated that glycoprotein component of some fungi spore mucilages, which are similar to animal microbial mucins, have exceptionally high affinity for binding some phenolic compounds and hence protecting them from the inhibitory effects of phenolics. However, the interaction between free tannins and microorganisms in the rumen is probably less than expected, because tannins often form complexes at ruminal $\mathrm{pH}$ with many organic compounds including polysaccharides, protein and minerals (McSweeney et al., 2001). Nonetheless, such interactions have been shown to result in 
net tannin effect loss of up to $78 \%$ in the rumen of goats fed Calliandra calothyrsus (Perez-Maldonado \& Norton, 1996). This, in theory, enables goats to cope with tanniferous substances in feed.

\section{Utility of animals' coping mechanisms: Are exogenous interventions necessary?}

Browsers' coping strategies are useful adaptive mechanisms that protect the animals from deleterious effects of tannins in their natural habitat. It is unlikely that detannification interventions would be necessary for animals that spend most of their time in their natural foraging habitat. Nevertheless, even under freeranging rearing systems, fluctuations in feed availability may interfere with the ability of the browser to fully exercise its avoidance behaviours, leading to negative nutritional and health effects (Terblance et al., 1967). The utility of browser coping strategies under other feeding conditions remains unknown. Indeed, most of the scientific investigations involving the use of exogenous agents to ameliorate tannin effects are carried out under intensive and semi-intensive rearing systems. Under these systems, the normal foraging behaviour of browsers may be restricted and thus animals are unable to rely fully on their behavioural responses to escape the negative effects of tannins. Behavioural activities such as differential and cautious sampling, increasing dietary breadth, ensuring complementarity of plant secondary metabolites and associative learning may be curtailed under intensive feeding systems, as well as in rearing systems that isolate animals, such as the use of individual feeding pens. Under these conditions, it may be justifiable to explore the use of exogenous agents such as PEG to protect the animal from negative tannins effects. However, browsers' physiological and microbial adaptations would play a prominent role in protecting animals from the detrimental effects of tannins even under these feeding systems. The production of PRPs is the first line of physiological defence. While there is little disagreement about the affinity of PRPs with tannins, there is ambiguity about the fate of PRP-tannin complexes as they pass through the digestive tract. Failure of these complexes to dissociate in the digestive system makes this physiological response a drain on the animals' nitrogen pool since the PRPs are lost in faeces. Clearly, the consumption of high levels of tannins would result in greater nitrogen losses from the animal, which could be prevented by the use of exogenous tannininactivating treatments. Most scientific investigations and recommendations on the use of detannifying agents have been made under feeding conditions that expose the animal to unusually high levels of tanninrich supplements. This indicates that researchers have adopted a safety-first approach, which may work, depending on the type of tannins present in the animals' feed. Scientific evidence indicates that in vitro ruminal fermentation of tanniferous forages still benefited from tannin inactivation with PEG, even though adapted rumen fluid, obtained from animals fed tannin-rich diets for 85 days, was used (Mlambo et al., 2007). While microbes in the adapted rumen fluid had acquired greater potency against tannins compared with those in unadapted rumen fluid, this was not sufficient to completely neutralize the inhibitory effects of tannins on ruminal fermentation. The ability of rumen microbes to adapt to dietary tannins has been extensively reported by McSweeney et al. (2001). However, indiscriminate inactivation of tannins is unlikely to improve the nutrition of browsers all the time, as seen in a study by Mlambo et al. (2004). In this study, better nitrogen retention figures were obtained in goats that were offered untreated $D$. cinerea fruits compared with those offered PEG-treated fruits. Laboratory tests for tannin bioactivity, such as protein precipitation assays, solution calorimetry and octanol-water partitioning coefficients, should inform decisions on whether exogenous tannin ameliorating strategies are necessary. However, even these tests may not accurately predict the nutritional or anti-nutritional effects of tannins.

\section{Conclusion}

In conclusion, animals' behavioural coping strategies may not be sufficient under certain feeding systems and conditions. When animals are exposed to higher than normal levels of tannins, and are unable to express their normal feeding behaviour, exogenous tannin-inactivating strategies may be justifiable. Yet, even under these feeding conditions, inactivating dietary tannins may reduce the nutritional quality of an animal's diet, particularly the efficiency of nitrogen utilization.

\section{References}

Aganga, A.A. \& Tshwenyane, S.O., 2003. Feeding values and anti-nutritive factors of forage tree legumes. Pakistan J. Nutr. 2 (3), 170-177.

Alonso-Díaz, M.A., Torres-Acosta, J.F.J., Sandoval-Castro, C.A. \& Hoste, H., 2010. Tannins in tropical tree fodders fed to small ruminants: a friendly foe? Small Rumin. Res. 89, 164-173.

Ammar, H., López, S., Salem, A.Z.M., Bodasa, R. \& González, J.S., 2011. Effect of saliva from sheep that have ingested quebracho tannins on the in vitro rumen fermentation activity to digest tannin-containing shrubs. Anim. Feed Sci. Technol. 163, 77-83. 
Athanasiadou, S., Kyriazakis, I., Jackson, F. \& Coop, R.L., 2000. Consequences of long-term feeding with condensed tannins on sheep parasitized with Trichostrongylus colubriformis. Int. J. Parasitol. 30, 1025-1033.

Athanasiadou, S., Kyriazakis, I., Jackson, F. \& Coop, R.L., 2001. Direct anthelmintics effects of condensed tannins towards different gastrointestinal nematodes of sheep: In vitro and in vivo studies. Vet. Parasitol. 99, 205-219.

Barry, T.N., 1989. Condensed tannins: Their role in ruminant protein and carbohydrate digestion and possible effects upon the rumen ecosystem. In: The Roles of Protozoa and Fungi in Ruminant Digestion. Eds: Nolan, J.V., Leng, R.A. \& Demeyer, D.I., Penambul Books, University of New England, Armidale, NSW 2351, Australia. pp. 153-169.

Barry, T.N. \& McNabb, W.C., 1999. The implications of condensed tannins on the nutritive value of temperate forages fed to ruminants. Br. J. Nutr. 81, 263-272

Bodas, R., Prietoa, N., García-González, R., Andrés, S., Giráldez, F.J. \& López, S., 2012. Manipulation of rumen fermentation and methane production with plant secondary metabolites. Anim. Feed Sci. Technol. 176, 78-93.

Burritt, E.A. \& Provenza, F.D., 2000. Role of toxins in intake of varied diets by sheep. J. Chem. Ecol. 26, 1991-2005.

Busquet, M., Calsamiglia, S., Ferret, A., Cardozo, P. \& Kamel, C., 2005. Effects of cinnamaldehyde and garlic oil on rumen microbial fermentation in a dual flow continuous culture. J. Dairy Sci. 88, 2508-2516.

Cardozo, P., Calsamiglia, S., Ferret, A. \& Kamel, C., 2004. Effects of natural plant extracts on ruminal protein degradation and fermentation profiles in continuous culture. J. Anim. Sci. 82, 3230-3236.

Chiquette, J., Cheng, K.J., Costerton, J.W. \& Milligan, L.P., 1988. Effect of tannins on the digestibility of two isosynthetic strains of birdsfoot trefoil (Lotus corniculatus) using in vitro and in sacco techniques. Can. J. Anim. Sci. 68, 751-760.

Clauss, M., Lason, K., Gehrke, J., Lechner-Doll, M., Fickel, J., Grune, T. \& Streich, W.J., 2003. Captive roe deer (Capreolus capreolus) select for low amounts of tannic acid but not quebracho: Fluctuation of preferences and potential benefits. Comp. Biochem. Physiol, 369-382.

Distel, R.A. \& Provenza, F.D., 1991. Experience early in life affects voluntary intake of blackbrush by goats. J. Chem. Ecol. 17, 431-450.

Duncan, A.J. \& Young, S.A., 2002. Can goats learn about foods through conditioned food aversions and preferences when multiple food options are simultaneously available? J. Anim. Sci. 80, 2091-2098.

Duncan, A.J., Frutos, P. \& Young, S.A., 1997. Rates of oxalic acid degradation in the rumen of sheep and goats in response to different levels of oxalic acid administration. Anim. Sci. 65, 451-456.

Duncan, A.J., Frutos, P. \& Young, S.A., 2000. The effect of rumen adaptation to oxalic acid on selection of oxalic-acid-rich plants by goats. Br. J. Nutr. 83, 59-65.

Dziba, L.E. \& Provenza, F.D., 2008. Dietary monoterpene concentrations influence feeding patterns of lambs. Appl. Anim. Behav. Sci. 109, 49-57.

Estell, R.E., 2010. Coping with shrub secondary metabolites by ruminants. Small Rumin. Res. 94, 1-9.

Fagundes, G.M., Modesto, E.C., Fonseca, C.E.M., Lima, H.R.P. \& Muir, J.P., 2014. Intake, digestibility and milk yield in goats fed Flemingia macrophylla with or without polyethylene glycol. Small Rumin. Res. 116, 88-93.

Foley, W.J., Iason, G.R. \& McArthur, C., 1999. Role of plant secondary metabolites in the nutritional ecology of mammalian herbivores: How far have we come in 25 years? In: Nutritional Ecology of Herbivores. Eds: Jung, H.J.G., Fahey Jr., G.C., Proc. 5th Inter. Symp. Nutr. Herbivores. Am. Soc. Anim. Sci. Savoy, IL, pp. 130-209.

Freeland, W.J. \& Janzen, D.H., 1974. Strategies in herbivory by mammals: The role of plant secondary compounds. Amer. Nat. 108, 269-289.

Frutos, P., Raso, M., Hervas, G., Mantecon, A.R., Perez, V. \& Giraldez, F.J., 2004. Is there any detrimental effect when a chestnut hydrolyzable tannins extract is included in the diet of finishing lambs? Anim. Res. 56, 127-136.

Gilboa, N., Nir, I., Nitsan, Z., Silanikove, N. \& Perevolotsky, A., 1995. Effect of polyethylene glycol on feed intake, body weight and digestibility in goats fed tannin-rich leaves. Hassadeh 75, 72-73.

Gilboa, N., Perevolotsky, A., Landaub, S., Nitsana, Z. \& Silanikove, N., 2000. Increasing productivity in goats grazing Mediterranean woodland and scrubland by supplementation of polyethylene glycol. Small Rumin. Res. 38, 183-190.

Glendinning, J.I., 1994. Is the bitter rejection response always adaptive? Physiol. Behav. 56, 1217-1227.

Griffiths, D.W., 1991. Condensed tannins. Toxic substances in crop plants. Royal Soc. Chem. Cambridge. 46, 180-201. 
Hedqvist, H., Mueller-Harvey, I., Reed, J.D., Krueger, C.G. \& Murphy, M., 2000. Characterisation of tannins and in vitro protein digestibility of several Lotus corniculatus varieties. Anim. Feed Sci. Technol. 87, 41-56.

Hervás, G., Pérez, V., Giráldez, F.J., Mantecón, A.R., Almar, M.M. \& Frutos P., 2003. Intoxication of sheep with quebracho tannin extract. J. Comp. Path. 129, 44-54.

Hoskin, S.O., Wilson, P.R., Barry, T.N., Charleson, W.A.G. \& Waghorn, G.C., 2000. Effect of forage legumes containing condensed tannins on lungworm (Dictyocaulus sp.) and gastro-intestinal parasitism in young red deer (Ceryus elaphus). Res. Vet. Sci. 68, 223-230.

Illius, A.W. \& Jessop, N.S., 1995. Modelling metabolic costs of allelochemical ingestion by foraging herbivores. J. Chem. Ecol. 21, 693-719.

Jason, G.R. \& Murray, A.H., 1996. The energy costs of ingestion of naturally occurring nontannin plant phenolics by sheep. Physiol. Zool. 69, 532-546.

Kakes, P., 1991. The genetics and ecology of variation in secondary plant substances. In: Ecological Responses to Environmental Stresses. Eds: Rozema, J. \& Verkleij, J.A.C., Kluwer Academic Publishers, Dordrecht, Netherlands. pp. 234-249.

Krause, D.O., Smith, W.J.M., Brooker, J.D. \& McSweeney, C.S., 2005. Tolerance mechanisms of streptococci to hydrolysable and condensed tannins. Anim. Feed Sci. Technol. 121, 59-75.

Majak, W., 2001. Review of toxic glycosides in rangeland and pasture forages. J. Range Manage. 54, 494-498.

Makkar, H.P.S., 2003. Effects and fate of tannins in ruminant animals, adaptation to tannins, and strategies to overcome detrimental effects of feeding tannin-rich feeds. Small Rumin. Res. 49, 241-256.

Makkar, H.P.S. \& Becker, K., 1998. Do tannins in leaves of trees and shrubs from African and Himalayan regions differ in level and activity? Agrofor. Sys. 40, 59-68.

Marsh, K.J., Wallis, I.R., Andrew, R.L. \& Foley, W.J., 2006. The detoxification limitation hypothesis: where did it come from and where is it going? J. Chem. Ecol. 32, 1247-1266.

McLean, S. \& Duncan, A.J., 2006. Pharmacological perspectives on the detoxification of plant secondary metabolites: Implications for ingestive behavior of herbivores. J. Chem. Ecol. 32, 1213-1228.

McSweeney, C.S., Palmer, B., McNeill, D.M. \& Krause, D.O., 2001. Microbial interactions with tannins: nutritional consequences for ruminants. Anim. Feed Sci. Technol. 91, 83-93.

Mehansho, H., Hagerman, A., Clements, S., Butler, L., Rogler, J. \& Carlson, D.M., 1983. Modulation of praline-rich protein biosynthesis in rat parotid glands by sorghums with high tannin levels. Proc. Natl. Acad. Sci. USA 80, 3948-3952.

Mehansho, H., Clements, S., Sheares, B.T., Smith, S. \& Carlson, D.M., 1985. Induction of proline-rich glycoprotein synthesis in mouse salivary glands by isoproterenol and by tannins. J. Biol. Chem. 260, 4418-4423.

Mehansho, H., Butler, L.G. \& Carlson, D.M., 1987. Dietary tannins and salivary proline-rich proteins: interactions, induction and defense mechanisms. Annu. Rev. Nutr. 7, 423-440.

Min, B.R., Barry, T.N., Attwood, G.T. \& McNabb, W.C., 2003. The effect of condensed tannins on the nutrition and health of ruminants fed fresh temperate forages: a review. Anim. Feed Sci. Technol. 106, 3-19.

Mkhize, N.R., Heitköniga, I.M.A., Scogings, P.F., Dziba, L.E., Prins, H.H.T. \& de Boer, W.F., 2015. Condensed tannins reduce browsing and increase grazing time of free-ranging goats in semi-arid savannas. Appl. Anim. Behav. Sci. http://dx.doi.org/10.1016/j.applanim.2015.04.012.

Mlambo, V. \& Mapiye, C., 2015. Towards household food and nutrition security in semi-arid areas: What role for condensed tannin-rich ruminant feedstuffs? Food Res. Int. 76, 953-961.

Mlambo, V., Smith, T., Owen, E., Mould, F.L., Sikosana, J.L.N. \& Mueller-Harvey, I., 2004. Tanniniferous Dichrostachys cinerea fruits do not require detoxification for goat nutrition: In sacco and in vivo evaluations. Livest. Prod. Sci. 90, 135-144

Mlambo, V., Sikosana, J.L.N., Mould, F.L., Smith, T., Owen, E. \& Mueller-Harvey, I., 2007. The effectiveness of adapted rumen fluid versus PEG to ferment tannin-contain substrates in vitro. Anim. Feed Sci. Technol. 136, 128-136.

Mlambo, V., Sikosana, J.L.N., Smith, T., Owen, E., Mould, F.L. \& Mueller-Harvey, I., 2011. An evaluation of $\mathrm{NaOH}$ and wood ash for the inactivation of tannins in Acacia nilotica and Dichrostachys cinerea fruits using an in vitro rumen fermentation technique. Trop. Agric. (Trinidad) 88, 44-54.

Moore, B.D., Wallis, I.R., Paul, J.P., Brophy, J.J., Willis, R.H. \& Foley, W.J., 2004. Antiherbivore chemistry of Eucalyptus_cues and deterrents for marsupial folivores. J. Chem. Ecol. 30, 1743-1769.

Mueller-Harvey, I., 1999. Tannins: their nature and biological significance. In: Secondary Plants Products. Antinutritional and Beneficial Actions in Animal Feeding. Eds: Caygill J.C. \& Mueller-Harvey, I., Nottingham University Press, UK. pp. 17-70. 
Mueller-Harvey, I., 2006. Unravelling the conundrum of tannins in animal nutrition and health. A review. J. Sci. Food Agric. 86, 2010-2037.

Mueller-Harvey, I. \& McAllan, A.B., 1992. Tannins. Their biochemistry and nutritional properties. In: Advances in Plant Cell Biochemistry and Biotechnology, Vol. 1. Ed: Morrison, I.M., JAI Press Ltd., London, UK, pp. 151-217.

Mueller-Harvey, I., Mlambo, V., Sikosana, J.L.N., Smith, T., Owen, E. \& Brown, R.H., 2007. Octanol-water partition coefficients for predicting the effects of tannins in ruminant nutrition. J. Agric. Food Chem. 55, 5436-5444.

Narvaez, N., Brosh, A., Mellado, M. \& Pittroff, W., 2011. Performance of sheep and goats fed Arctostaphylos canescens with and without polyethylene glycol supplementation. Rangel. Ecol. Manage. 64, 85-91.

Newbold, C.J., El Hassan, S.M., Wang, J., Ortega, M. \& Wallace, R.J., 1997. Influence of foliage from African multipurpose trees on activity of rumen protozoa and bacteria. Br. J. Nutr. 78, 237-249.

Nicholson, R.L., Butler, L.G. \& Asquith, T.N., 1986. Glycoproteins from Colletotrichum graminicola that bind phenols: Implications for survival and virulence of phytopathogenic fungi. Phytopathol. 76, 1315-1318.

O`Donovan, L. \& Brooker, J.D., 2001. Effect of hydrolysable and condensed tannins on growth, morphology and metabolism of Streptococcus gallolyticus (S. caprinus) and Streptococcus bovis. Microbiology 147, 1025-1033.

Owen, J.B., 1992. Genetic aspects of appetite and food choice in animals. J. Agric. Sci., Camb. 119, 151155.

Perevolotsky, A., Landau, S., Silanikove, N. \& Provenza, F.D., 2006. Upgrading tannin-rich forages by supplementing ruminants with polyethylene glycol (PEG). In: Herbivores: Assessment of Intake, Digestibility and the Roles of Secondary Compounds. Eds: Sandoval-Castro, C.A., Hovell, D., TorresAcosta, J.F.J. \& Ayala-Burgos, A., Nottingham Univ. Press, Nottingham, UK. pp. 221-233.

Perez-Maldonado, R.A. \& Norton, B.W., 1996. The effects of condensed tannins from Desmodium intortum and Calliandra calothyrsus on protein and carbohydrate digestion in sheep and goats. Br. J. Nutr. 76, 515-533.

Pfister, J.A., 1999. Behavioral strategies for coping with poisonous plants. In: Grazing Behavior of Livestock and Wildlife. Eds: Launchbaugh, K.L., Sanders, K.D. \& Mosley, J.C., Idaho Forest, Wildlife, and Range Exp. Sta. Bull. No. 70. Moscow, Idaho, USA. pp. 45-59.

Provenza, F.D., 1995. Postingestive feedback as an elementary determinant of food preference and intake in ruminants. J. Range Manage. 48, 2-17.

Provenza, F.D., 1996. Acquired aversions as the basis for varied diets of ruminants foraging on rangelands. J. Anim. Sci. 74, 2010-2020.

Provenza, F.D., Lynch, J.J. \& Nolan, J.V., 1993. The relative importance of mother and toxicosis in the selection of foods by lambs. J. Chem. Ecol. 19, 313-323.

Rogosic, J., Estell, R.E., Skobic, D. \& Stanic, S., 2007. Influence of secondary compound complementarity and species diversity on consumption of Mediterranean shrubs by sheep. Appl. Anim. Behav. Sci. 107, 58-65.

Rogosic, J., Estell, R.E., Ivankovic, S., Kezic, J. \& Razov, J., 2008. Potential mechanisms to increase shrub intake and performance of small ruminants in Mediterranean shrubby ecosystems. Small Rumin. Res. 74, 1-15.

Salem, A.Z.M., Salem, M.Z.M., El-Adawy, M.M. \& Robinson, P.H., 2006. Nutritive evaluations of some browse tree foliages during the dry season: secondary compounds, feed intake and in vivo digestibility in sheep and goats. Anim. Feed Sci. Technol. 127, 251-267.

Santos-Buelga, C. \& Scalbert, A., 2000. Proanthocyanidins and tannin-like compounds - nature, occurrence, dietary intake and effects on nutrition and health. J. Sci. Food Agric. 80, 1094-1117.

Shimada, T., 2006. Salivary proteins as a defence against dietary tannins. J. Chem. Ecol. 32, 1149-1163.

Silanikove, N., Gilboa, N. \& Nitsan, Z., 1997. Interactions among tannins, supplementation and polyethylene glycol in goats given oak leaves: Effects on digestion and food intake. Anim. Sci. 64, 479-483.

Silanikove, N., Perevolotsky, A. \& Provenza, F.D., 2001. Use of tannin-binding chemicals to assay for tannins and their negative post-ingestive effects in ruminants. Anim. Feed Sci. Technol. 91, 69-81.

Smith, A.H., Wallig, M.A., Seigler, D.S., Odenyo, A.A., McSweeney, C.S. \& Mackie, R.I., 2003. Ameliorating the toxic effects of Acacia angustissima with polyethylene glycol in rats. Anim. Feed Sci. Technol. 106, 165-174.

Smith, A.H., Zoetendal, E. \& Mackie, R.I., 2005. Bacterial mechanisms to overcome inhibitory effects of dietary tannins. Microb. Ecol. 50, 197-205.

Smith, T., Mlambo, V., Sikosana, J.L.N., Maphosa, V., Mueller-Harvey, I. \& Owen, E., 2005. Dichrostachys cinerea and Acacia nilotica fruits as dry season feed supplements for goats in a semi-arid 
environment: Summary of a DFID funded project in Zimbabwe. Anim. Feed Sci. Technol. 122, 149-157.

Teferedegne, B., 2000. New perspectives on the use of tropical plants to improve ruminant nutrition. Proc. Nutr. Soc. 59, 209-214.

Terblance, M., Pienaar, J.G., Bigalki, R. \& Vahrmeyer, J., 1967. Acacia nilotica (L.) del subsp. Kraussiana (Benth.) Brenan as a poisonous plant in South Africa. J. S. Afr. Vet. Med. Assoc. 38, 57-63.

Thorhallsdottir, A.G., Provenza, F.D. \& Balph, D.F., 1990. The role of mother in the intake of harmful foods by lambs. Appl. Anim. Behav. Sci. 25, 35-44.

Utsumi, S.A., Cibils, A.F., Estell, R.E., Soto-Navarro, S.A. \& Van Leeuwen, D., 2009. Seasonal changes in one seed juniper intake by sheep and goats in relation to protein and plant secondary metabolites. Small Rumin. Res. 81, 152-162.

Villalba, J.J. \& Provenza, F.D., 2002. Polyethylene glycol influences selection of foraging location by sheep consuming quebracho tannin. J. Anim. Sci. 80, 1846-1851.

Villalba, J.J., Provenza, F.D. \& Banner, R.E., 2002. Influence of macronutrients and polyethylene glycol on intake of a quebracho tannin diet by sheep and goats. J. Anim. Sci. 80, 3154-3164.

Waghorn, G., 2008. Beneficial and detrimental effects of dietary condensed tannins for sustainable sheep and goat production - Progress and challenges. Anim. Feed Sci. Technol. 147, 116-139.

Weimer, P.J., 1998. Manipulating ruminal fermentation: A microbial ecological perspective. J. Anim. Sci. 76, 3114-3122.

Zimmerman, H.J., 1978. Hepatotoxicity: The Adverse Effects of Drugs and Other Chemicals on the Liver. Appleton-Century-Crofts, N.Y., USA. 